\title{
Multi-institutional prospective observational study of the effectiveness of eribulin in first-line or second-line chemotherapy for HER2-negative hormone-resistant advanced or metastatic breast cancer: The KBCRN A001: E-SPEC Study
}

Yuichiro Kikawa ( $\square$ bj.u1ro@gmail.com )

Kansai Medical University Hirakata Hospital: Kansai Ika Daigaku Fuzoku Hirakata Byoin https://orcid.org/0000-0002-3852-5991

\section{Takeshi Kotake}

Kyoto University Hospital: Kyoto Daigaku Igakubu Fuzoku Byoin

\section{Shigeru Tsuyuki}

Osaka Red Cross Hospital: Osaka Sekijuji Byoin

\section{Yookija Kang}

Osaka Red Cross Hospital: Osaka Sekijuji Byoin

\section{Sachiko Takahara}

Tazuke Kofukai Medical Research Institute, Kitano Hospital

\section{Yuri Fujimoto}

Tazuke Kofukai Medical Research Institute, Kitano Hospital

Hiroyasu Yamashiro

Tenri Hospital: Koeki Zaidan Hojin Tenri Yorozu Sodanjo Byoin Ikoi no le

Hiroshi Yoshibayashi

Japan Red Cross Wakayama Medical Center: Nihon Sekijujisha Wakayama Iryo Center

\section{Masahiro Takada}

Kyoto University Hospital: Kyoto Daigaku Igakubu Fuzoku Byoin

\section{Rie Yasuoka}

Kyoto Prefectural University of Medicine: Kyoto Furitsu Ika Daigaku

\section{Katsuhiko Nakatsukasa}

Kyoto Prefectural University of Medicine: Kyoto Furitsu Ika Daigaku

\section{Kazuhiko Yamagami}

Shinko Memorial Hospital: Shinko Kinen Byoin

\section{Hirofumi Suwa}

Hyogo Prefectural Amagasaki General Medical Center: Hyogo Kenritsu Amagasaki Sogo Iryo Center Toshitaka Okuno 
Nishi Kobe Medical Center: Kobe Shiritsu Nishi Kobe Iryo Center

\section{Ichiro Nakayama}

Kyoto Min-iren Chuo Hospital

\section{Tatsuji Kato}

Yamato Takada Municipal Hospital

\section{Nobuko Ogura}

Kansai Electric Power Hospital: Kansai Denryoku Byoin

\section{Yoshio Moriguchi}

Kyoto City Hospital: Kyoto Shiritsu Byoin

\section{Hiroshi Ishiguro}

Saitama Medical University International Medical Center: Saitama Ika Daigaku Kokusai Iryo Center

\section{Tatsuo Kagimura}

Foundation for Biomedical Research and Innovation: Sentan Iryo Kenkyu Center

\section{Tetsuya Taguchi}

Kyoto Prefectural University of Medicine: Kyoto Furitsu Ika Daigaku

\section{Tomoharu Sugie}

Kansai Medical University Hirakata Hospital: Kansai Ika Daigaku Fuzoku Hirakata Byoin

\section{Masakazu Toi}

Kyoto University Hospital: Kyoto Daigaku Igakubu Fuzoku Byoin

\section{Research Article}

Keywords: Breast cancer, Metastasis, Eribulin, Chemotherapy sequence

Posted Date: April 14th, 2021

DOI: https://doi.org/10.21203/rs.3.rs-412075/v1

License: () (1) This work is licensed under a Creative Commons Attribution 4.0 International License. Read Full License 


\section{Abstract}

\section{Purpose}

To investigate the survival impact of eribulin use in first-line and second-line chemotherapy for patients with endocrine-resistant advanced or metastatic breast cancer (AMBC) in the real-world clinical setting.

\section{Methods}

This multi-institutional prospective cohort study enrolled patients with triple-negative AMBC or estrogen receptor (ER)-positive AMBC refractory to at least one previous endocrine therapy selected at the physician's discretion. The overall survival from the start of first-line (OS1) and second-line chemotherapy (OS2) were assessed. Adjusted hazard ratio (HR) between eribulin and the other regimens (oral 5fluorouracil [5-FU] and anthracycline/taxane) was calculated using a stratified proportional hazards model that included prespecified prognostic factors.

\section{Results}

Of the 201 patients enrolled, 180 were included in the final analysis. Baseline patient characteristics were quite diverse among regimens. The median OS1 was 2.25, 3.49, and 2.62 years for eribulin $(n=46)$, oral 5FU ( $n=57)$, and anthracycline/taxane ( $n=71)$, and the median OS2 was 1.75, 2.33, and 1.69 years for eribulin ( $n=70)$, oral 5 -FU $(n=26)$, and anthracycline/taxane $(n=44)$, respectively. First-line eribulin had a worse adjusted HR for OS than the other regimens in the ER-negative cohort; second-line oral 5-FU had a better adjusted HR for OS than eribulin in the ER-positive cohort. There was no significant difference between regimens in the other subgroups.

\section{Conclusions}

Eribulin and anthracycline/taxane resulted in similar point estimates for OS, while oral 5-FU led to relatively longer survival. Adjusted HRs differed based on treatment line and ER status. However, caution should be exercised when interpreting the results due to the heterogamies in patient background.

\section{Trial registration number and date of registration}

Clinical Trials.gov (NCT 02551263), July 22, 2015.

\section{Introduction}

In recent years, screening mammography has been utilized widely, and the number of patients with early stage breast cancer (BC) has increased. However, despite the increase in early cancer detection, the number of patients with advanced or metastatic breast cancer (AMBC) has not decreased [1]. The 5-year survival rate of patients with $A M B C$ is less than $25 \%$, and the patients are very unlikely to be cured $[2,3]$. Therefore, the main objectives in the treatment of $A M B C$ are to prolong overall survival (OS) and maintain 
the quality of life (QOL). Prior to treatment initiation, treatment-related factors, such as the estrogen receptor (ER), progesterone receptor (PgR), human epidermal growth factor receptor 2 (HER2), and menopausal status and clinical symptoms, are carefully evaluated to facilitate shared decision-making by the patients and physicians on which drugs should be used, as indicated in the treatment strategy presented by Hortobagyi [4]. This strategy has been indicated over the years based on the premise that the use of cytotoxic chemotherapy should be delayed as much as possible in ER-positive AMBC unless the patient is in a visceral crisis.

Recently, the effectiveness of immune checkpoint inhibitors and poly-ADP-ribose polymerase (PARP) inhibitors has been demonstrated in some patients with HER2-negative BC $[5,6]$. However, a limited number of patients with programmed death ligand 1 (PD-L1)-positive triple-negative or BRCA-mutationpositive $B C$ are available to receive targeted therapy. Therefore, chemotherapy is generally indicated for many $A M B C$ patients with endocrine therapy-refractory ER-positive or triple-negative BC. For first-line chemotherapy, based on available evidence $[7,8]$ and guidelines $[2,9]$, anthracycline or taxane-based regimens are common choices for patients who have not been treated previously with (neo) adjuvant chemotherapy comprising those drugs. A recent clinical trial in Japan demonstrated that first-line S-1, an oral 5-fluorouracil (FU) regimen, was non-inferior to docetaxel or paclitaxel in terms of OS [10]. As secondline chemotherapy, anthracyclines or taxanes are recommended when they are not used as first-line treatment [2, 9]. For subsequent regimens, the European Society for Medical Oncology guideline recommends single-agent capecitabine, vinorelbine, or eribulin therapy as the preferred choice, while factoring in the following aspects: tumor responsiveness to the previous treatment, patient's performance status, possible adverse events of the drug, and QOL.

Eribulin is a novel chemotherapeutic drug that binds to a different microtubule site wherein taxane acts, and it inhibits the microtubule motility in cancer cells $[11,12]$. In a phase III study (EMBRACE) for AMBC previously treated with anthracyclines and taxanes, eribulin monotherapy significantly prolonged OS when compared with the physician's treatment selection [hazard ratio (HR) $0.81,95 \%$ confidence interval (CI) $0.66-0.99 ; p=0.041$ ] [ [13]. In this study, OS was prolonged despite similar progression-free survival (PFS) between the eribulin and control groups, and a similar trend was observed in Study 301 that compared eribulin with capecitabine [14]. Moreover, as third-line or later chemotherapy in sarcoma patients, eribulin prolonged OS more than the conventional standard treatment of dacarbazine (HR 0.768 , $95 \% \mathrm{Cl} 0.618-0.954, p=0.0169)$ despite no significant difference in PFS [15]. The reason for this difference between PFS and OS, as shown in basic research, is that eribulin inhibits epithelialmesenchymal transition (EMT) or angiogenesis [16-18]. Furthermore, the time to the occurrence of new fatal metastases, such as to the lung, liver, and brain, was an important factor for a worse prognosis in an exploratory analysis of the pivotal study of eribulin and in our retrospective study [19, 20]. Although there are few single-arm phase II studies on the early line use of eribulin [21-24], the reason of the abovementioned survival benefit and optimal sequences of chemotherapy for patients with AMBC are still unclear. In Japan, off-label eribulin treatment is sometimes used in the early line setting for AMBC in patients without a history of anthracycline and taxane treatment because of the expectation of an OS- 
prolongation effect. Hence, we considered that we could evaluate the appropriate application of eribulin in the real-world setting.

The primary aim of this study was to investigate the OS of first-and second-line chemotherapy in the realworld clinical setting among different regimens, and the secondary aims were to evaluate optimal chemotherapy schedule and the clinicopathological factors that contribute to OS prolongation with eribulin use.

\section{Patients And Methods}

\section{Study design and participants}

This multi-institutional, prospective, observational cohort study enrolled consecutive patients with AMBC who were treated between July 2015 and July 2017 at 1 of the 27 institutions of the Kyoto Breast Cancer Research Network (KBCRN) that participated in this study. The inclusion criteria were as follows: 1) female sex with histologically or cytologically confirmed AMBC, 2) HER2-negative status defined according to the American Society of Clinical Oncology (ASCO)/College of American Pathologists guideline in 2014 [25], 3) resistant to endocrine therapy, 4) scheduled to receive first- or second-line chemotherapy at their physician's discretion, 5) aged between 20 and 75 years, 6) Eastern Cooperative Oncology Group (ECOG) Performance Status (PS) of 0-3, and 7) adequate bone marrow and major organ function at the discretion of the attending physician. The exclusion criteria were as follows: 1) symptomatic metastasis in the central nervous system, 2) allergic/hypersensitive to any ingredients of drugs included in the scheduled treatment, and 3) unsuitable for study participation, as evaluated by the primary physician.

The scheduled observation period was 2.5 years from the last patient's enrolment in the study. Details of the treatment regimen, laboratory data, vital signs, and 5-level EuroQol 5 Dimensions (EQ-5D-5L) scores prior to the start of each chemotherapy as well as the determinants of treatment efficacy were investigated until the end of third-line chemotherapy. Furthermore, the following baseline variables that could affect outcomes were recorded: medical history, complications, smoking status, cancer stage, hormone receptor status, history of adjuvant chemotherapy and adjuvant endocrine therapy, and metastatic sites.

The appropriate ethics committee or institutional review board at each study site approved the final protocol. This study was conducted in accordance with the Japanese Guidelines for Clinical Research of the Ministry of Health, Labour and Welfare and the Declaration of Helsinki. All participants provided written informed consent prior to study participation. This study is registered with Clinical Trials.gov (NCT 02551263).

\section{Definition of resistance to endocrine therapy}


In this study, "resistance to endocrine therapy" was defined by the presence of at least one of the following criteria: 1 ) both ER- and PgR-negative status on immunohistochemical analysis of the primary or recurrent lesions according to the ASCO/College of American Pathologists guidelines [26]. In cases with discordant results between the primary and recurrent lesions, the result of the recurrent lesion was considered; 2) refractory to at least one endocrine therapy in ER-positive AMBC (subsequent endocrine therapy after initiation of chemotherapy was acceptable at the discretion of the attending physician); and 3) relapse during adjuvant endocrine therapy or within 6 months after the completion of adjuvant endocrine therapy.

\section{Definition of lines of chemotherapy}

The lines of chemotherapy were defined as follows: The first-line treatment was the first chemotherapy for hormone-resistant or triple-negative AMBC. However, in cases where induction chemotherapy was administered for hormone receptor-positive $A M B C$ that was endocrine therapy-naive but received maintenance endocrine therapy, the induction chemotherapy was not included in the first-line treatment. Therefore, first-line chemotherapy was defined as the first chemotherapy for tumors refractory to maintenance endocrine therapy. Only one induction chemotherapy regimen was allowed.

Second- or third-line chemotherapy was defined as a subsequent chemotherapy administered after disease progression or after adverse event-related withdrawal of the previous chemotherapy. For patients with recurrence during postoperative adjuvant chemotherapy, the chemotherapy cycle immediately before recurrence was defined as the first-line treatment, whereas the regimen just after recurrence was defined as the second-line treatment.

\section{Treatment}

After study enrolment, treatment according to the general practice was administered at the attending physician's discretion. Moreover, dose modifications, chemotherapy schedules, and decisions of treatment discontinuation were based on the physician's evaluation and shared decision-making by patients and physicians. Furthermore, subsequent endocrine therapies after chemotherapy initiation were allowed for hormone receptor-positive patients, although these therapies were not counted in the treatment lines. Molecular targeted drugs, such as palbociclib, abemaciclib, or everolimus, which are used in combination with endocrine therapy, were classified as endocrine therapy and not as chemotherapy.

\section{Outcomes}

The primary endpoint was the first-line OS (OS1), defined as the time from the start of first-line chemotherapy to death from any cause. The secondary endpoints were the second-line OS (OS2) and third-line OS (OS3), which were defined as the time from the start of second-and third-line chemotherapy, respectively. Moreover, PFS, time to treatment failure, new metastasis-free survival, safety, and EQ-5D-5L scores were evaluated. The analysis of the utility score assessed with EQ-5D-5L has been presented in another report.

\section{Statistical analysis}


The full analysis set included all enrolled patients, excluding those deemed ineligible after enrolment because they had not received the allocated treatment or had no data after treatment. The cumulative survival rate was estimated using the Kaplan-Meier method. The number of events, incidence (/100 person-years; $95 \%$ confidence intervals [CI]), and median survival time $(95 \% \mathrm{Cl})$ were calculated for eribulin, oral 5-FU, and anthracycline/taxane-based chemotherapy regimens. Adjusted hazard ratios with $95 \% \mathrm{Cls}$ for the comparisons of eribulin with oral 5-FU and an anthracycline/taxane regimen were calculated using a stratified proportional hazards model that included age, body mass index, smoking, menopausal status, cerebrovascular decease, diabetes, TNM classification N, TNM classification M, histological grade, hormone receptor status, disease-free interval, endocrine therapy, (neo) adjuvant chemotherapy, radiation therapy, ECOG PS at first-line chemotherapy, metastasis recurrence site, liver metastasis, lung metastasis, and brain metastasis as covariates after stratification by the timing of registration.

All analyses were conducted using SAS version 9.4 (Cary, NC, USA). The significance level was set to $p<$ 0.05 (2-tailed).

\section{Results}

\section{Patient characteristics}

We enrolled 201 patients, but the data of 21 were excluded from the full analysis set for the following reasons: first-line chemotherapy was not administered to 16, 2 were ineligible (one case was found to be HER2 positive after enrolment, and the other was enrolled from third-line treatment), 2 withdrew consent, and 1 was registered erroneously. The median age of 180 patients treated with first-line chemotherapy was 61 years (range 29-75 years), and the baseline patient characteristics are shown in Table 1. Among those, 146 and 101 patients underwent second- and third-line chemotherapy, respectively. The study participant flow is shown in Fig. 1. Eribulin was used for 116 patients as first- or second-line chemotherapy, whereas oral 5-FU, taxane, and anthracycline were used for 83, 99, and 16 patients, respectively, as first- or second-line chemotherapy. 
Table 1

Patient characteristics of the cohorts based on first-line chemotherapy

\section{Characteristics}

First-line ChT regimen
ER-negative cohort**

$\begin{array}{lll}n= & n=128 & n=52\end{array}$

Timing of registration

\begin{tabular}{|c|c|c|c|c|c|c|c|}
\hline $\begin{array}{l}\text { Registration in first-line ChT, n } \\
(\%)\end{array}$ & $\begin{array}{l}99 \\
(55.0)\end{array}$ & $\begin{array}{l}31 \\
(96.9)\end{array}$ & $\begin{array}{l}22 \\
(48.9)\end{array}$ & $\begin{array}{l}22 \\
(45.8)\end{array}$ & $\begin{array}{l}13 \\
(92.9)\end{array}$ & $1(8.3)$ & $\begin{array}{l}7 \\
(30.4)\end{array}$ \\
\hline $\begin{array}{l}\text { Registration in second-line ChT, } \\
\mathrm{n}(\%)\end{array}$ & $\begin{array}{l}81 \\
(45.0)\end{array}$ & $\begin{array}{l}1 \\
(3.1)\end{array}$ & $\begin{array}{l}23 \\
(51.1)\end{array}$ & $\begin{array}{l}26 \\
(54.2)\end{array}$ & $\begin{array}{l}1 \\
(7.1)\end{array}$ & $\begin{array}{l}11 \\
(91.7)\end{array}$ & $\begin{array}{l}16 \\
(69.6)\end{array}$ \\
\hline median (range) & $\begin{array}{l}61 \\
(29- \\
75)\end{array}$ & $\begin{array}{l}61 \\
(44- \\
75)\end{array}$ & $\begin{array}{l}64 \\
(40- \\
75)\end{array}$ & $\begin{array}{l}59 \\
(34- \\
74)\end{array}$ & $\begin{array}{l}61 \\
(29- \\
74)\end{array}$ & $\begin{array}{l}64(36- \\
75)\end{array}$ & $\begin{array}{l}61 \\
(41- \\
74)\end{array}$ \\
\hline Age $\geq$ & $\begin{array}{l}30 \\
(16.7)\end{array}$ & $\begin{array}{l}10 \\
(31.3)\end{array}$ & $\begin{array}{l}7 \\
(15.6)\end{array}$ & $\begin{array}{l}4 \\
(8.3)\end{array}$ & $\begin{array}{l}4 \\
(28.6)\end{array}$ & $2(16.7)$ & $\begin{array}{l}3 \\
(13.0)\end{array}$ \\
\hline
\end{tabular}

Menopausal status, $\mathrm{n}(\%)$

Premenopausal

Postmenopausal

Unknown

Performance Status, n (\%)

$0-1$

$2-3$

Unknown

$\begin{array}{ll}163 & \\ (90.6) & (87 \\ 12 & \\ (6.7) & (12) \\ 5 & \\ (2.8)\end{array}$

(1)

$\begin{array}{llllll}\text { E } & \text { FU } & \text { A/T } & \text { E } & 5-F U & A / T \\ n=32 & n=45 & n=48 & n=14 & n=12 & n=23\end{array}$

Total ER-positive cohort* $n=14$ 


\begin{tabular}{|c|c|c|c|c|c|c|c|}
\hline \multirow{2}{*}{$\begin{array}{l}\text { Characteristics } \\
\text { Invasive ductal carcinoma }\end{array}$} & \multirow{2}{*}{$\begin{array}{l}\text { Total } \\
\mathrm{n}= \\
180 \\
121 \\
(67.2)\end{array}$} & \multicolumn{3}{|c|}{$\begin{array}{l}\text { ER-positive cohort* } \\
n=128\end{array}$} & \multicolumn{3}{|c|}{$\begin{array}{l}\text { ER-negative cohort** } \\
n=52\end{array}$} \\
\hline & & $\begin{array}{l}20 \\
(62.5)\end{array}$ & $\begin{array}{l}32 \\
(71.1)\end{array}$ & $\begin{array}{l}29 \\
(60.4)\end{array}$ & $\begin{array}{l}12 \\
(85.7)\end{array}$ & $\begin{array}{l}11 \\
(91.7)\end{array}$ & $\begin{array}{l}14 \\
(60.9)\end{array}$ \\
\hline Invasive lobular carcinoma & $\begin{array}{l}7 \\
(3.9)\end{array}$ & $\begin{array}{l}2 \\
(6.3)\end{array}$ & $\begin{array}{l}3 \\
(6.7)\end{array}$ & $\begin{array}{l}2 \\
(4.2)\end{array}$ & $\begin{array}{l}0 \\
(0.0)\end{array}$ & $0(0.0)$ & $\begin{array}{l}0 \\
(0.0)\end{array}$ \\
\hline Special type & $\begin{array}{l}3 \\
(1.7)\end{array}$ & $\begin{array}{l}2 \\
(6.3)\end{array}$ & $\begin{array}{l}1 \\
(2.2)\end{array}$ & $\begin{array}{l}0 \\
(0.0)\end{array}$ & $\begin{array}{l}0 \\
(0.0)\end{array}$ & $0(0.0)$ & $\begin{array}{l}0 \\
(0.0)\end{array}$ \\
\hline Unknown & $\begin{array}{l}49 \\
(27.2)\end{array}$ & $\begin{array}{l}8 \\
(25.0)\end{array}$ & $\begin{array}{l}8 \\
(17.8)\end{array}$ & $\begin{array}{l}17 \\
(35.4)\end{array}$ & $\begin{array}{l}2 \\
(14.3)\end{array}$ & $1(8.3)$ & $\begin{array}{l}9 \\
(39.1)\end{array}$ \\
\hline \multicolumn{8}{|l|}{$\begin{array}{l}\text { Disease-free interval, years, } n \\
(\%)\end{array}$} \\
\hline$\leq 2$ & $\begin{array}{l}36 \\
(20.2)\end{array}$ & $\begin{array}{l}6 \\
(18.8)\end{array}$ & $\begin{array}{l}3 \\
(6.7)\end{array}$ & $\begin{array}{l}4 \\
(8.3)\end{array}$ & $\begin{array}{l}8 \\
(57.1)\end{array}$ & $6(50.0)$ & $\begin{array}{l}8 \\
(34.8)\end{array}$ \\
\hline $2-5$ & $\begin{array}{l}47 \\
(26.1)\end{array}$ & $\begin{array}{l}10 \\
(31.3)\end{array}$ & $\begin{array}{l}16 \\
(35.6)\end{array}$ & $\begin{array}{l}12 \\
(25.0)\end{array}$ & $\begin{array}{l}2 \\
(14.3)\end{array}$ & $2(16.7)$ & $\begin{array}{l}3 \\
(13.0)\end{array}$ \\
\hline $5-8$ & $\begin{array}{l}22 \\
(12.2)\end{array}$ & $\begin{array}{l}4 \\
(12.5)\end{array}$ & $\begin{array}{l}6 \\
(13.3)\end{array}$ & $\begin{array}{l}9 \\
(18.8)\end{array}$ & $\begin{array}{l}0 \\
(0.0)\end{array}$ & $3(25.0)$ & $\begin{array}{l}0 \\
(0.0)\end{array}$ \\
\hline$>8$ & $\begin{array}{l}21 \\
(11.7)\end{array}$ & $\begin{array}{l}1 \\
(3.1)\end{array}$ & $\begin{array}{l}10 \\
(22.2)\end{array}$ & $\begin{array}{l}5 \\
(10.4)\end{array}$ & $\begin{array}{l}2 \\
(14.3)\end{array}$ & $0(0.0)$ & $\begin{array}{l}3 \\
(13.0)\end{array}$ \\
\hline Stage 4 & $\begin{array}{l}42 \\
(23.3)\end{array}$ & $\begin{array}{l}7 \\
(21.9)\end{array}$ & $\begin{array}{l}8 \\
(17.8)\end{array}$ & $\begin{array}{l}14 \\
(29.2)\end{array}$ & $\begin{array}{l}2 \\
(14.3)\end{array}$ & $1(8.3)$ & $\begin{array}{l}9 \\
(39.1)\end{array}$ \\
\hline $\begin{array}{l}\text { Inoperable locally advanced } \\
\text { cancer }\end{array}$ & $\begin{array}{l}3 \\
(1.7)\end{array}$ & & & & & & \\
\hline Unknown & $\begin{array}{l}9 \\
(5.0)\end{array}$ & & & & & & \\
\hline $\begin{array}{l}\text { (Neo) Adjuvant chemotherapy, } \\
\mathrm{n}(\%)\end{array}$ & $\begin{array}{l}98 \\
(54.4)\end{array}$ & $\begin{array}{l}19 \\
(59.4)\end{array}$ & $\begin{array}{l}25 \\
(55.6)\end{array}$ & $\begin{array}{l}19 \\
(39.6)\end{array}$ & $\begin{array}{l}10 \\
(71.4)\end{array}$ & $\begin{array}{l}11 \\
(91.7)\end{array}$ & $\begin{array}{l}13 \\
(56.5)\end{array}$ \\
\hline $\begin{array}{l}\text { Concurrent or maintenance } \\
\text { endocrine therapy, } \mathrm{n}(\%)\end{array}$ & $\begin{array}{l}37 \\
(20.6)\end{array}$ & $\begin{array}{l}7 \\
(15.2)\end{array}$ & $\begin{array}{l}18 \\
(31.6)\end{array}$ & $\begin{array}{l}10 \\
(14.1)\end{array}$ & $\begin{array}{l}0 \\
(0.0)\end{array}$ & $0(0.0)$ & $\begin{array}{l}0 \\
(0.0)\end{array}$ \\
\hline \multicolumn{8}{|l|}{$\begin{array}{l}\text { Metastatic sites at first-line } \\
\text { ChT, } n(\%)\end{array}$} \\
\hline \multicolumn{8}{|l|}{ Liver } \\
\hline \multicolumn{8}{|c|}{$\begin{array}{l}\text { ER, estrogen receptor; PgR, progesterone receptor; ChT, chemotherapy; E, eribulin; 5-FU, oral 5- } \\
\text { fluorouracil; A/T, anthracycline or taxane }\end{array}$} \\
\hline \multicolumn{8}{|c|}{ *Three patients who received $\mathrm{ChT}$ other than $\mathrm{E}, 5-\mathrm{FU}$, and $\mathrm{A} / \mathrm{T}$. } \\
\hline${ }^{\star *}$ Three patients who re & he & $E, 5$ & nd & & & & \\
\hline
\end{tabular}




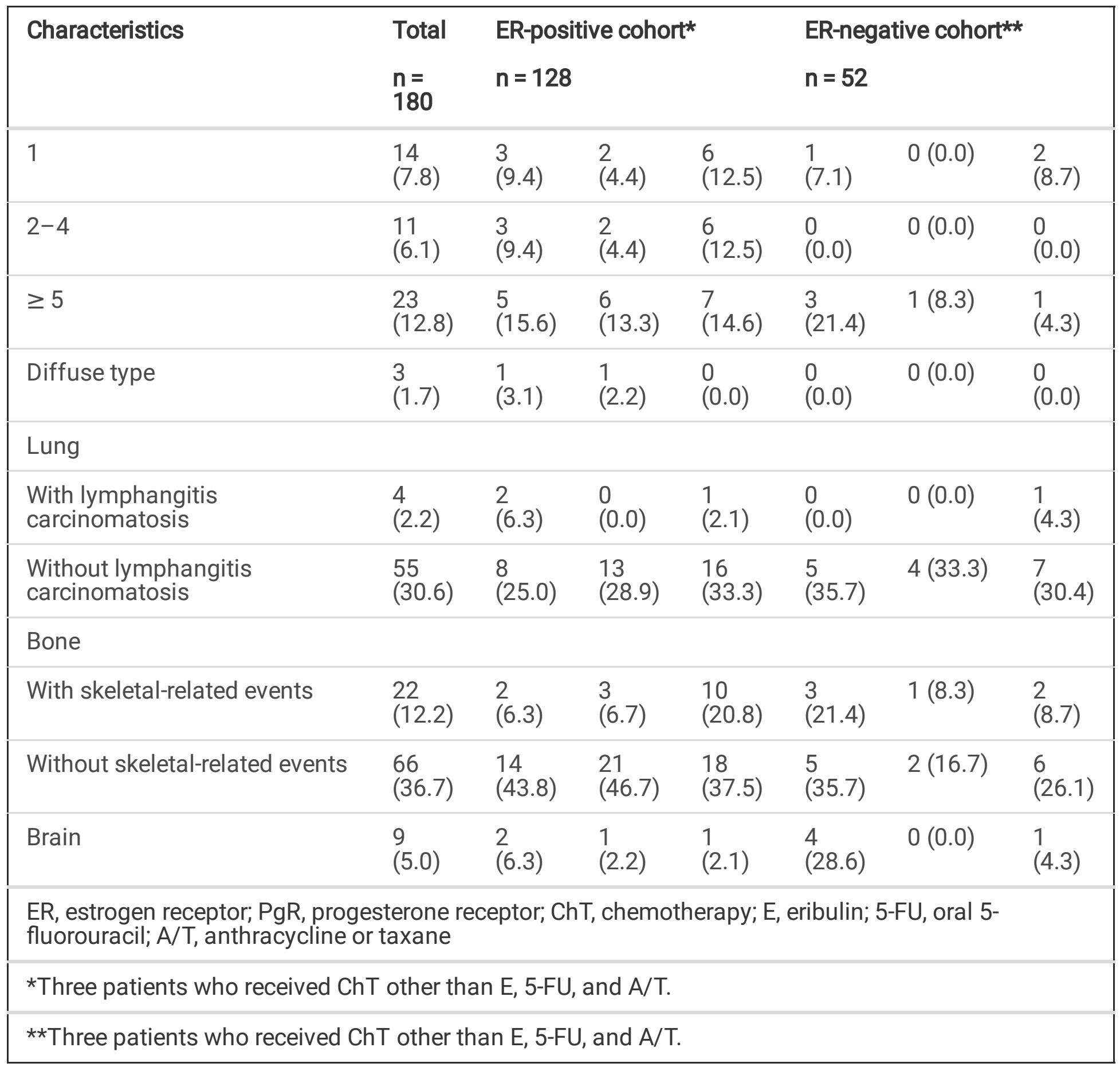

\section{Chemotherapy sequences}

The sequences of chemotherapy followed in this study are shown in Fig. 2. The frequent first- and second-line chemotherapy sequences were as follows: taxanes followed by eribulin ( $n=33)$, oral 5-FUbased therapy followed by eribulin $(n=26)$, eribulin followed by taxanes $(n=21)$, taxanes followed by oral 5 -FU $(n=11)$, and eribulin followed by oral 5-FU $(n=10)$. Additionally, the reasons for the selection of eribulin by the participating physician despite not using anthracyclines or taxanes are shown in Supplementary Fig. S1. Eribulin was administered as first- or second-line therapy for patients who did not receive anthracyclines or taxanes when the main concern was "lower toxicity." 


\section{Overall survival}

The median OS1, OS2, and OS3 of all patients were $2.69,1.74$, and 1.13 years, respectively (Fig. 3a). The median OS1 by the ER status were 2.20 and 2.81 years in ER-negative and ER-positive patients, respectively (Fig. 3b). The median OS1 by the three first-line chemotherapies were 2.25, 3.49, and 2.62 years for eribulin $(n=46)$, oral 5 -FU $(n=57)$, and anthracycline/taxane $(n=71)$, whereas the median OS2 by the second-line chemotherapies were $1.75,2.33$, and 1.69 years for eribulin $(n=70)$, oral 5-FU $(n=26)$, and anthracycline/taxane $(n=44)$, respectively. The median OS1 by the three first-line chemotherapies in the ER-positive and ER-negative cohorts is shown in Fig. 4a and Fig. 4b, respectively. There was no difference in OS1 between the three regimens in the ER-positive cohort (adjusted HR for oral 5-FU vs. eribulin: $1.00,95 \% \mathrm{Cl} 047-2.12 ; p=0.990$ : adjusted HR for anthracycline/taxane vs. eribulin: $0.81,95 \% \mathrm{Cl}$ $0.38-1.69 ; p=0.579)$, whereas in the ER-negative cohort, OS1 with eribulin was shorter than that with the other regimens, and the difference was significant with anthracycline/taxane (adjusted HR for oral 5-FU vs. eribulin: $0.23,95 \% \mathrm{Cl} 0.03-2.05 ; p=0.189$ : adjusted $\mathrm{HR}$ for anthracycline/taxane vs. eribulin $0.18,95 \%$ Cl 0.04-0.95; $p=0.043$ ). The median OS2 evaluated for the three second-line chemotherapies in the ERpositive and ER-negative cohorts is shown in Fig. 4c and Fig. 4d, respectively. The median adjusted OS2 for eribulin was significantly shorter than that for oral 5-FU in the ER-positive cohort (adjusted HR for oral 5 -FU vs. eribulin: $0.35,95 \% \mathrm{Cl} 0.12-0.99 ; p=0.048)$, whereas there were no significant differences in the adjusted OS2 among the three regimens in the ER-negative cohort.

Data pertaining to OS, PFS, and new metastasis-free survival by treatment line and chemotherapy are presented in Supplementary Table S1. The OS1 durations with the three most frequently used first- to second-line chemotherapy sequences are shown in Supplementary Fig. S2.

\section{Prognostic factors regarding OS in patients who received eribulin as the first- or second-line chemotherapy}

The univariate and multivariate analyses of prognostic factors in patients who were treated with eribulin as the first- or second-line chemotherapy are shown in Table 2. Smoking, a higher lactate dehydrogenase $(\mathrm{LDH})$ score, and a lower utility score were associated with poor prognosis in patients treated with eribulin as the first- or second-line treatment. 
Table 2

Results from univariate/multivariate analysis of the baseline factors for OS1 in patients who were treated with eribulin in first-line or second-line chemotherapy

\begin{tabular}{|c|c|c|c|c|c|c|c|}
\hline \multirow[t]{2}{*}{ Variables } & \multirow{2}{*}{$\begin{array}{l}\text { Reference } \\
\text { group }\end{array}$} & \multicolumn{3}{|c|}{ Univariate analysis } & \multicolumn{3}{|c|}{ Multivariate analysis } \\
\hline & & HR & $95 \% \mathrm{Cl}$ & $\begin{array}{l}P \\
\text { value }\end{array}$ & HR & $\begin{array}{l}95 \% \\
\mathrm{Cl}\end{array}$ & $\begin{array}{l}P \\
\text { value }\end{array}$ \\
\hline Age, $\geq 65$ years & $<65$ & 0.81 & $\begin{array}{l}0.51- \\
1.29\end{array}$ & 0.372 & 1.20 & $\begin{array}{l}0.68- \\
2.12\end{array}$ & 0.532 \\
\hline$P S \geq 1$ & 0 & 1.11 & $\begin{array}{l}0.70- \\
1.75\end{array}$ & 0.656 & 1.13 & $\begin{array}{l}0.64- \\
2.00\end{array}$ & 0.680 \\
\hline $\mathrm{BMI} \geq 25$ & $<25$ & 1.01 & $\begin{array}{l}0.60- \\
1.68\end{array}$ & 0.975 & 0.81 & $\begin{array}{l}0.44- \\
1.50\end{array}$ & 0.503 \\
\hline Former \& current smoker & $\begin{array}{l}\text { Never } \\
\text { smoker }\end{array}$ & 1.43 & $\begin{array}{l}0.85- \\
2.40\end{array}$ & 0.180 & 2.22 & $\begin{array}{l}1.12- \\
4.39\end{array}$ & 0.022 \\
\hline $\begin{array}{l}\text { Regional lymph node metastasis } \\
\text { at diagnosis }\end{array}$ & No & 1.47 & $\begin{array}{l}0.87- \\
2.48\end{array}$ & 0.146 & 1.52 & $\begin{array}{l}0.79- \\
2.93\end{array}$ & 0.214 \\
\hline Disease-free interval, years & Stage4 & & $\begin{array}{l}0.75- \\
2.74\end{array}$ & & & $\begin{array}{l}0.10- \\
3.22\end{array}$ & 0.525 \\
\hline$<2$ & & 0.71 & & 0.284 & 0.33 & & 0.251 \\
\hline $2-5$ & & 0.62 & 1.32 & 0.147 & 0.37 & $\begin{array}{l}0.05- \\
2.19\end{array}$ & 0.327 \\
\hline$>5$ & & & $\begin{array}{l}0.32- \\
1.19\end{array}$ & & & $\begin{array}{l}0.05- \\
2.68\end{array}$ & \\
\hline ER-negative status & Positive & 1.27 & $\begin{array}{l}0.80- \\
2.01\end{array}$ & 0.319 & 1.06 & $\begin{array}{l}0.56- \\
1.99\end{array}$ & 0.862 \\
\hline Histological grade 3 & 1 or 2 & 1.79 & $\begin{array}{l}1.00- \\
3.19\end{array}$ & 0.049 & 1.50 & $\begin{array}{l}0.66- \\
3.37\end{array}$ & 0.331 \\
\hline Adjuvant hormone therapy & No & 0.45 & $\begin{array}{l}0.26- \\
0.78\end{array}$ & 0.005 & 0.45 & $\begin{array}{l}0.20- \\
1.02\end{array}$ & 0.054 \\
\hline (Neo) adjuvant chemotherapy & No & 1.24 & $\begin{array}{l}0.78- \\
1.96\end{array}$ & 0.360 & 1.33 & $\begin{array}{l}0.83- \\
2.12\end{array}$ & 0.231 \\
\hline Postoperative radiation therapy & No & 0.90 & $\begin{array}{l}0.58- \\
1.41\end{array}$ & 0.658 & 1.48 & $\begin{array}{l}0.76- \\
2.90\end{array}$ & 0.254 \\
\hline Liver metastasis & No & 1.17 & $\begin{array}{l}0.71- \\
1.93\end{array}$ & 0.533 & 1.10 & $\begin{array}{l}0.59- \\
2.06\end{array}$ & 0.767 \\
\hline Lung metastasis & No & 1.12 & $\begin{array}{l}0.70- \\
1.79\end{array}$ & 0.630 & 1.67 & $\begin{array}{l}0.90- \\
3.10\end{array}$ & 0.104 \\
\hline
\end{tabular}

OS1, overall survival from the start of first-line chemotherapy; $\mathrm{HR}$, hazard ratio; $\mathrm{Cl}$, confidence interval; PS, performance status; BMI, body mass index; ER, estrogen receptor 


\begin{tabular}{|c|c|c|c|c|c|c|c|}
\hline \multirow[t]{2}{*}{ Variables } & \multirow{2}{*}{$\begin{array}{l}\text { Reference } \\
\text { group }\end{array}$} & \multicolumn{3}{|c|}{ Univariate analysis } & \multicolumn{3}{|c|}{ Multivariate analysis } \\
\hline & & HR & $95 \% \mathrm{Cl}$ & $\begin{array}{l}P \\
\text { value }\end{array}$ & HR & $\begin{array}{l}95 \% \\
\mathrm{Cl}\end{array}$ & $\begin{array}{l}P \\
\text { value }\end{array}$ \\
\hline Brain metastasis & No & 3.10 & $\begin{array}{l}1.46- \\
6.57\end{array}$ & 0.003 & 2.47 & $\begin{array}{l}0.95- \\
6.42\end{array}$ & 0.064 \\
\hline Cerebrovascular disease & No & 0.49 & $\begin{array}{l}0.07- \\
3.54\end{array}$ & 0.479 & 0.56 & $\begin{array}{l}0.05- \\
6.09\end{array}$ & 0.630 \\
\hline Diabetes & No & 0.69 & $\begin{array}{l}0.34- \\
1.40\end{array}$ & 0.305 & 0.76 & $\begin{array}{l}0.30- \\
1.95\end{array}$ & 0.570 \\
\hline Lactate dehydrogenase $\geq 300$ & $<300$ & 3.43 & $\begin{array}{l}2.05- \\
5.75\end{array}$ & $\begin{array}{l}< \\
0.001\end{array}$ & 3.39 & $\begin{array}{l}1.76- \\
6.50\end{array}$ & $\begin{array}{l}<.001 \\
0.00\end{array}$ \\
\hline Baseline utility score $<0.81$ & $\geq 0.81$ & 2.29 & $\begin{array}{l}1.33- \\
3.97\end{array}$ & 0.003 & 2.38 & $\begin{array}{l}1.05- \\
5.44\end{array}$ & 0.039 \\
\hline
\end{tabular}

\section{Adverse event-related discontinuation for each drug}

The proportions of adverse event-related discontinuations for eribulin, oral 5-FU, and anthracycline/taxane are shown in Fig. 5. Patients treated with eribulin or oral 5-FU as first-line chemotherapy had significantly less discontinuation owing to adverse events than those treated with anthracyclines or taxanes $(p=0.038)$.

\section{Discussion}

To the best of our knowledge, this is the first multicenter prospective cohort study to follow the sequences of chemotherapy, from the first to third line, that were used for patients with AMBC in routine clinical practice in Japan. Most importantly, this study found that eribulin and oral 5-FU were as effective as anthracycline/taxane, which have long been considered the gold standard in first-line chemotherapy for AMBC.

As the main purpose was to survey the actual use of chemotherapy and to investigate the effectiveness of eribulin in early line chemotherapy in Japan, all therapeutic agents were selected by shared decisionmaking that was based on patient-physician discussions. The study participants had quite diverse backgrounds and, among those, the patients who received eribulin as first-line treatment had many poor prognostic factors. For example, in the ER-positive cohort, more patients treated with eribulin relapsed within 2 years; in the ER-negative cohort, more patients had liver and brain metastases than patients who were treated with the other regimens. The reasons for this trend may be as follows: 1) eribulin was more likely to be chosen for patients with early recurrence after adjuvant chemotherapy with anthracyclines or taxanes; 2) there might have been an expectation, based on the EMBRACE trial, that early use of eribulin 
would prolong OS [13]; and 3) metronomic therapy, such as oral 5-FU, was more likely to be chosen for patients with a slow tumor growth.

The frequent first- and second-line chemotherapy sequences were taxane followed by eribulin $(n=33)$, oral 5-FU-based therapy followed by eribulin $(n=26)$, and eribulin followed by taxane $(n=21)$. It was suggested that the relatively high use of eribulin as first-line $(n=46,26.6 \%)$ and second-line $(n=70$, $47.9 \%$ ) chemotherapy was the result of shared decision making by the patients and treating physician in the hope of lowering chemotherapy-related toxicity. These treatment choices may have been based on the differences in the adverse event profiles, such as less frequent gastrointestinal symptoms or peripheral neuropathy, with regard to regimens other than oral 5-FU or taxanes, respectively. The time to the deterioration of global health status was longer for patients with eribulin use than for those with capecitabine use in triple-negative BC in Study 301 [27]. Similarly, the finding of a better health-related QOL in patients treated with S-1 than in those treated with taxanes as first-line therapy in the SELECT-BC trial [10] might provide an impression to the patient and physician that oral 5-FU could lead to better QOL. In this study, the lower proportion of adverse events and lower discontinuation rate of eribulin and oral 5FU as first-line therapy reflect the better feasibility of these two treatments. For the comparison between eribulin and S-1, further results of a randomized controlled trial (UMIN ID 000021398), (eribulin vs. S-1) with health-related QOL as the primary endpoint, which is currently being conducted in Japan, are awaited.

As first-line treatment, eribulin was as effective as anthracycline/taxane and oral 5-FU for patients with ER-positive AMBC, whereas the prognosis in the eribulin cohort was worse for ER-negative patients. However, as described above, there were poor prognostic factors in the patients treated with eribulin as first-line chemotherapy, especially in the ER-negative cohort. Thus, the possibility of selection bias cannot be ignored even after adjusting for background variables, while considering that OS1 following eribulin in ER-negative patients was shorter than OS1 (2.99 years) that was previously reported in a phase II study [21], which investigated the efficacy of eribulin as first-line chemotherapy. In contrast, OS1 for oral 5-FUs in this cohort was longer than the OS reported in a large, randomized controlled trial [10] that investigated first-line chemotherapy in Japan (OS: 2.92 years in the S-1 group). This might indicate that oral 5-FUs were used for patients with less aggressive AMBC in this study. In contrast, OS2 or OS3 following eribulin was similar to those of two large randomized controlled trials (Study 301: 1.33 years, mainly in the second- or third-line chemotherapy; EMBRACE: 1.09 years, mainly in third-line or later chemotherapy) [13, 14].

The results of the multivariate analysis of the data of patients who used eribulin as first- or second-line chemotherapy demonstrated that higher LDH levels ( $\geq 300 \mathrm{U} / \mathrm{L}$ ), smoking history, and lower utility scores were associated with shorter OS1. An elevated serum LDH level is known to be a worse prognostic factor in many cancer patients [28]. Tumor cell hypoxia leads to anaerobic glycolysis, which increases the LDH level and, consequently, the lactate level. In turn, lactate leads to local acidosis in the surrounding microenvironment and, as a result, tumor immunity and drug delivery are compromised [29]. Moreover, it has been suggested that smoking affects tumor immunity, such as through high infiltration of regulatory 
T-cells [30] and alteration of the phenotype of macrophages [31]. The abovementioned factors may diminish the efficacy of chemotherapy. Nevertheless, eribulin reportedly affects the improvement of hypoxia and causes EMT suppression, which is considered one of the reasons for OS prolongation [1618]. Therefore, further large-sample studies are necessary to investigate this contradictory finding. Miyoshi et al. reported that high baseline absolute lymphocyte counts $(\geq 1500)$ are a predictive factor for eribulin use [32]; however, we found no significant interaction of eribulin with the lymphocyte count in the exploratory analysis of this study (data not shown). Therefore, no specific predictive factors could be identified. However, it interesting to note that the utility score became a prognostic factor, and this suggests the importance of patient-reported outcome measures rather than physician-rated PS.

This study has some limitations. There were a limited number of participating institutions, and the sample size was small, leading to lack of power to discern confounding effects of other drugs used in sequence with eribulin. There was a possibility of channeling bias affecting the choice of treatment by the attending physician, as patients expected effectiveness and better feasibility with eribulin based on the results of pivotal studies. The survivor treatment selection bias that possibly exists in patients enrolled from second-line chemotherapy might have contributed to a favorable outcome for those patients. Furthermore, there were differences in the study treatment from the current standard of care because immune checkpoint inhibitors and PARP inhibitors were not approved for clinical use at that time in Japan. However, no other cohort study has followed the actual treatment sequence up to third-line chemotherapy, and this study provides valuable data on the actual status of chemotherapy for patients with AMBC.

In conclusion, we demonstrated the treatment sequences of first-, second-, and third-line chemotherapy for HER2-negative AMBC in the real-world setting, and eribulin or oral 5-FU was commonly used for firstand second-line chemotherapy. The lower proportion of adverse events and lower discontinuation rate of eribulin and oral 5-FU in early line chemotherapy may be attributable to the better feasibility of these treatments. OS1 for eribulin was shorter in the ER-negative cohort, whereas there was no difference in OS1 between all three regimens in the ER-positive cohort. Eribulin as first-line chemotherapy was used for patients with poor prognostic factors, whereas oral 5-FU was used for patients with less aggressive AMBC in this study. Therefore, the results of this study should be interpreted cautiously. The efficacy of eribulin in early line chemotherapy should be validated in randomized controlled trials.

\section{Declarations}

\section{Acknowledgments}

The Translational Research Center for Medical Innovation conducted this study jointly with the Kobe City Medical Center General Hospital, Kyoto University Hospital, and the other medical institutions.

We would like to thank Ms. Nomura, Ms. Nakagawa, Mr. Kidena and the investigators involved in the KBCRN E-SPEC study as well as the patients participating in the study. 
We also would like to thank Editage (www.editage.com) for English language editing.

\section{Funding}

This study was funded by Eisai Co., Ltd. Eisai was not involved in the design and conduct of the study or in the data analysis and interpretation of the results. A quadripartite contract for conducting this study was made between Eisai, Kobe City Medical Center General Hospital, Kyoto University and TRI.

\section{Compliance with ethical standards}

\section{Conflict of Interest}

Yuichiro Kikawa received honoraria from Eisai, Novartis, Pfizer, Eli Lilly, Taiho, and Chugai, outside the submitted work. Hiroyasu Yamashiro received honoraria from Chugai, Daiich-Sankyo, Pfizer, Kyowa Kirin, Eisai, Eli Lilly, Takeda, and Taiho, outside the submitted work. Masahiro Takada received honoraria from Chugai, AstraZeneca, Pfizer, Eli Lilly, Eisai, Daiichi Sankyo, and Kyowa-Kirin, and grants from Eisai and Nipponkayaku, outside the submitted work. Tatsuo Kagimura received grants from Eisai, during the conduct of the study. Tetsuya Taguchi received honoraria from Eisai, Daiichi Sankyo, and Chugai, outside the submitted work. Tomoharu Sugie received honoraria from Chugai, Eisai, Pfizer, Astra Zeneca, Lilly, MSD, Novaris, Takeda, Kyowa-Kirin, Genomic Health, and Devicor, and grants from KBBM, outside the submitted work. Masakazu Toi received grants and honoraria from Chugai, Takeda, Pfizer, Kyowa-HakkoKirin, Taiho, Eisai, Daiichi-Sankyo, Astra Zeneca, Shimadzu, and Nippon Kayaku, and honoraria from Eli Lilly, MSD, Genomic Health, Novartis, Konica Minolta, BMS, and Yakult, and grants from JBCRG association, Astellas, and AFI technologies, outside the submitted work, and board of directors of JBCRG association, Organisation for Oncology and Translational Research, and Kyoto Breast cancer Research Network. The remaining authors have no conflicts of interest to disclose.

\section{Ethical approval}

All procedures were performed in accordance with the Helsinki declaration and the ethical standards of the institutional research committee. Informed consent was obtained from all study participants.

\section{Author contributions}

Yuichiro Kikawa: Conceptualization, project administration, data acquisition, and writing-original draft. Takeshi Kotake, Shigeru Tsuyuki, Sachiko Takahara, Hiroyasu Yamashiro, Hiroshi Yoshibayashi, Masahiro Takada: Conceptualization, project administration, data acquisition, and writing review. Yookija Kang, Yuri Fujimoto, Rie Yasuoka, Katsuhiko Nakatsukasa, Kazuhiko Yamagami, Hirofumi Suwa, Toshitaka Okuno, Ichiro Nakayama, Tatsuji Kato, Nobuko Ogura, Yoshio Moriguchi: Data acquisition and writing review. Tatsuo Kagimura: Data curation and analysis. Hiroshi Ishiguro, Tetsuya Taguchi, Tomoharu Sugie, Masakazu Toi: Supervision and writing review. 


\section{References}

[1] Bleyer A, Welch HG (2012) Effect of three decades of screening mammography on breast-cancer incidence. N Engl J Med 367:1998-2005. https://doi.org/10.1056/NEJMoa1206809

[2] Cardoso F, Paluch-Shimon S, Senkus E, Curigliano G, Aapro MS, André F, Barrios CH, Bergh J, Bhattacharyya GS, Biganzoli L, Boyle F, Cardoso MJ, Carey LA, Cortés J, El Saghir NS, Elzayat M, Eniu A, Fallowfield L, Francis PA, Gelmon K, Gligorov J, Haidinger R, Harbeck N, Hu X, Kaufman B, Kaur R, Kiely BE, Kim SB, Lin NU, Mertz SA, Neciosup S, Offersen BV, Ohno S, Pagani O, Prat A, Penault-Llorca F, Rugo HS, Sledge GW, Thomssen C, Vorobiof DA, Wiseman T, Xu B, Norton L, Costa A, Winer EP (2020) 5th ESOESMO international consensus guidelines for advanced breast cancer (ABC 5). Ann Oncol 31:1623-1649. https://doi.org/10.1016/j.annonc.2020.09.010

[3] Cardoso F, Spence D, Mertz S, Corneliussen-James D, Sabelko K, Gralow J, Cardoso MJ, Peccatori F, Paonessa D, Benares A, Sakurai N, Beishon M, Barker SJ, Mayer M (2018) Global analysis of advanced/metastatic breast cancer: decade report (2005-2015). Breast 39:131-138. https://doi.org/10.1016/j.breast.2018.03.002

[4] Hortobagyi GN (1998) Treatment of breast cancer. N Engl J Med 339:974-984. https://doi.org/10.1056/NEJM199810013391407

[5] Schmid P, Adams S, Rugo HS, Schneeweiss A, Barrios CH, Iwata H, Diéras V, Hegg R, Im SA, Shaw Wright G, Henschel V, Molinero L, Chui SY, Funke R, Husain A, Winer EP, Loi S, Emens LA; IMpassion130 Trial Investigators (2018) Atezolizumab and nab-paclitaxel in advanced triple-negative breast cancer. $\mathrm{N}$ Engl J Med 379:2108-2121. https://doi.org/10.1056/NEJMoa1809615

[6] Robson M, Im SA, Senkus E, Xu B, Domchek SM, Masuda N, Delaloge S, Li W, Tung N, Armstrong A, Wu W, Goessl C, Runswick S, Conte P (2017) Olaparib for metastatic breast cancer in patients with a germline BRCA mutation. N Engl J Med 377:523-533. https://doi.org/10.1056/NEJMoa1706450

[7] Katsumata N, Watanabe T, Minami H, Aogi K, Tabei T, Sano M, Masuda N, Andoh J, Ikeda T, Shibata T, Takashima S (2009) Phase III trial of doxorubicin plus cyclophosphamide (AC), docetaxel, and alternating $\mathrm{AC}$ and docetaxel as front-line chemotherapy for metastatic breast cancer: Japan Clinical Oncology Group trial (JCOG9802). Ann Oncol 20:1210-1215. https://doi.org/10.1093/annonc/mdn781

[8] Sledge GW, Neuberg D, Bernardo P, Ingle JN, Martino S, Rowinsky EK, Wood WC (2003) Phase III trial of doxorubicin, paclitaxel, and the combination of doxorubicin and paclitaxel as front-line chemotherapy for metastatic breast cancer: an intergroup trial (E1193). J Clin Oncol 21:588-592.

https://doi.org/10.1200/JC0.2003.08.013

[9] Shimoi T, Nagai SE, Yoshinami T, Takahashi M, Arioka H, Ishihara M, Kikawa Y, Koizumi K, Kondo N, Sagara Y, Takada M, Takano T, Tsurutani J, Naito Y, Nakamura R, Hattori M, Hara F, Hayashi N, Mizuno T, Miyashita M, Yamashita N, Yamanaka T, Saji S, Iwata H, Toyama T (2020) The Japanese Breast Cancer 
Society Clinical Practice Guidelines for systemic treatment of breast cancer, 2018 edition. Breast Cancer 27:322-331. https://doi.org/10.1007/s12282-020-01085-0

[10] Takashima T, Mukai H, Hara F, Matsubara N, Saito T, Takano T, Park Y, Toyama T, Hozumi Y, Tsurutani J, Imoto S, Watanabe T, Sagara Y, Nishimura R, Shimozuma K, Ohashi Y, Mukai H, Rai Y, Osumi S, Ishikawa T, Hozumi Y, Watanabe T, Watatani M, Imoto S, Nishimura R, Takatsuka Y, Yamashita H, Saito T, Watanabe K, Nakagami K, Park Y, Ueo H, Eguchi K, Ono S, Doihara H, Akabane H, Yoshida M, Nishi T, Iwata H, Wakabayashi T, Teramoto M, Tokunaga E, Ogino N, Hashizume T, Murakami S, Mizuno T, Kikawa Y, Masuda N, Kimura M, Ishikawa T, Narita Y, Maeda S, Watanabe N, Ito T, Takagane A, Hisamatsu K, Hamaguchi Y, Omura T, Hashizume T, Ishitobi M, Yamagami K, Imai T, Kato H, Tamauchi T, Doi F, Kamei K, Nakano Y, Onishi K, Tangoku A, Ito Y, Tashiro H, Kakugawa Y, Tanaka M, Yoshihara H, Tokunaga Y, Makino H, Matsui A, Suzuki A, Miyoshi Y, Tachibana A, Hattori H, Wada Y, Kuroda T, Yoshino H, Anan K, Kimijima I, Nishi T, Kunimoto Y, Kato H, Yoneyama K, Sawada T, Ryo T, Yamamoto Y, Kato M, Nomizu T, Kou J, Fujimori M, Shiba E, Takeuchi H, Imai S, Gon G, Earashi M, Ohno K, Komaki K, Miyazawa Y, Zawa H, Hasegawa S, Tanakaya K, Abe M, Iwamoto M, Kamigaki S, Suzuki Y, Yokota T, Saito M, Tamura A, Oyama K, Hashimoto T, Ichida T, Okuno T, Sonoda N, Chiba A, Kosaka T, Matsumoto T, Okamoto Y, Matsunami N, Tokuda Y, Ueki H, Tamura H, Jinno H, Suzuki H, Kaneda Y, Nishino M, Kawakami S, Ishizaka M, Shigemori C, Mase T, Ogasawara K, Manaka D, Aihara T, Yamauchi A, Takata D, Okada K, Wada M, Toda S, Kitani A, Morimoto T, Sato T, Taniguchi M, Miura D, Takao S, Yoshida M, Sagawa T, Haga S, Goto H, Takahashi T, Hayashi M, Ogasawara Y, Furuta A, Hanyu N, Ri T, Muramoto K, Takami M, Ogata H, Fukuzawa K, Kuranami M, Matutani Y, Tokunaga Y, Yanagida Y, Hashimoto N, Aono T (2016) Taxanes versus S-1 as the first-line chemotherapy for metastatic breast cancer (SELECT BC): an openlabel, non-inferiority, randomised phase 3 trial. Lancet Oncol 17:90-98. https://doi.org/10.1016/S14702045(15)00411-8

[11] Jordan MA, Kamath K, Manna T, Okouneva T, Miller HP, Davis C, Littlefield BA, Wilson L (2005) The primary antimitotic mechanism of action of the synthetic halichondrin E7389 is suppression of microtubule growth. Mol Cancer Ther 4:1086-1095. https://doi.org/10.1158/1535-7163.MCT-04-0345

[12] Smith JA, Wilson L, Azarenko O, Zhu X, Lewis BM, Littlefield BA, Jordan MA (2010) Eribulin binds at microtubule ends to a single site on tubulin to suppress dynamic instability. Biochemistry 49:1331-1337. https://doi.org/10.1021/bi901810u

[13] Cortes J, O'Shaughnessy J, Loesch D, Blum JL, Vahdat LT, Petrakova K, Chollet P, Manikas A, Diéras V, Delozier T, Vladimirov V, Cardoso F, Koh H, Bougnoux P, Dutcus CE, Seegobin S, Mir D, Meneses N, Wanders J, Twelves C; EMBRACE (Eisai Metastatic Breast Cancer Study Assessing Physician's Choice Versus E7389) investigators. (2011) Eribulin monotherapy versus treatment of physician's choice in patients with metastatic breast cancer (EMBRACE): a phase 3 open-label randomised study. Lancet 377:914-923. https://doi.org/10.1016/S0140-6736(11)60070-6

[14] Kaufman PA, Awada A, Twelves C, Yelle L, Perez EA, Velikova G, Olivo MS, He Y, Dutcus CE, Cortes J (2015) Phase III open-label randomized study of eribulin mesylate versus capecitabine in patients with 
locally advanced or metastatic breast cancer previously treated with an anthracycline and a taxane. $J$ Clin Oncol 33:594-601. https://doi.org/10.1200/JC0.2013.52.4892

[15] Schöffski P, Chawla S, Maki RG, Italiano A, Gelderblom H, Choy E, Grignani G, Camargo V, Bauer S, Rha SY, Blay JY, Hohenberger P, D'Adamo D, Guo M, Chmielowski B, Le Cesne A, Demetri GD, Patel SR (2016) Eribulin versus dacarbazine in previously treated patients with advanced liposarcoma or leiomyosarcoma: a randomised, open-label, multicentre, phase 3 trial. Lancet 387:1629-1637. https://doi.org/10.1016/S0140-6736(15)01283-0

[16] Yoshida T, Ozawa Y, Kimura T, Sato Y, Kuznetsov G, Xu S, Uesugi M, Agoulnik S, Taylor N, Funahashi Y, Matsui J (2014) Eribulin mesilate suppresses experimental metastasis of breast cancer cells by reversing phenotype from epithelial-mesenchymal transition (EMT) to mesenchymal-epithelial transition (MET) states. Br J Cancer 110:1497-1505. https://doi.org/10.1038/bjc.2014.80

[17] Kashiwagi S, Asano Y, Goto W, Takada K, Takahashi K, Hatano T, Tanaka S, Takashima T, Tomita S, Motomura H, Ohsawa M, Hirakawa K, Ohira M (2018) Mesenchymal-epithelial transition and tumor vascular remodeling in eribulin chemotherapy for breast cancer. Anticancer Res 38:401-410. https://doi.org/10.21873/anticanres.12236

[18] Funahashi Y, Okamoto K, Adachi Y, Semba T, Uesugi M, Ozawa Y, Tohyama O, Uehara T, Kimura T, Watanabe H, Asano M, Kawano S, Tizon X, McCracken PJ, Matsui J, Aoshima K, Nomoto K, Oda Y (2014) Eribulin mesylate reduces tumor microenvironment abnormality by vascular remodeling in preclinical human breast cancer models. Cancer Sci 105:1334-1342. https://doi.org/10.1111/cas.12488

[19] Twelves C, Cortes J, Kaufman PA, Yelle L, Awada A, Binder TA, Olivo M, Song J, O'Shaughnessy JA, Jove M, Perez EA (2015) "New" metastases are associated with a poorer prognosis than growth of preexisting metastases in patients with metastatic breast cancer treated with chemotherapy. Breast Cancer Res 17:150. https://doi.org/10.1186/s13058-015-0657-1

[20] Kotake T, Kikawa Y, Takahara S, Tsuyuki S, Yoshibayashi H, Suzuki E, Moriguchi Y, Yamashiro H, Yamagami K, Suwa H, Okuno T, Okamura T, Hashimoto T, Kato H, Tsuji A, Toi M (2016) Impact of eribulin monotherapy on post-progression survival in patients with HER2-negative advanced or metastatic breast cancer. Int J Cancer Clin Res 3:061. http://dx.doi.org/10.23937/2378-3419/3/4/1061

[21] Takashima T, Tokunaga S, Tei S, Nishimura S, Kawajiri H, Kashiwagi S, Yamagata S, Noda S, Nishimori T, Mizuyama Y, Sunami T, Tezuka K, Ikeda K, Ogawa Y, Onoda N, Ishikawa T, Kudoh S, Takada M, Hirakawa K (2016) A phase II, multicenter, single-arm trial of eribulin as first-line chemotherapy for HER2-negative locally advanced or metastatic breast cancer. Springerplus 5:164.

https://doi.org/10.1186/s40064-016-1833-1

[22] Hayashida T, Jinno H, Mori K, Sato H, Matsui A, Sakurai T, Hattori H, Takayama S, Wada M, Takahashi M, Seki H, Seki T, Nagayama A, Matsumoto A, Kitagawa Y (2018) Phase II trial of eribulin 
mesylate as a first- or second-line treatment for locally advanced or metastatic breast cancer: a multicenter, single-arm trial. BMC Cancer 18:701. https://doi.org/10.1186/s12885-018-4628-7

[23] Kimura K, Iwamoto M, Tanaka S, Yamamoto D, Yoshidome K, Ogura H, Terasawa R, Matsunami N, Takahashi Y, Nitta T, Morimoto T, Fujioka H, Kawaguchi K, Uchiyama K (2018) A phase II, multicenter, single-arm trial of eribulin as first- or second-line chemotherapy for HER2-negative advanced or metastatic breast cancer: evaluation of efficacy, safety, and patient-reported outcomes. Cancer Chemother Pharmacol 81:923-933. https://doi.org/10.1007/s00280-018-3567-y

[24] Ortega V, Antón A, Garau I, Afonso N, Calvo L, Fernández Y, Martínez-García M, Blanco E, Zamora P, García M, Illarramendi JJ, Rodríguez Sánchez CA, Sampayo M, Aguirre E, Pérez-García JM, Cortés J, Llombart-Cussac A (2019) Phase II, multicenter, single-arm trial of eribulin as first-line therapy for patients with aggressive taxane-pretreated HER2-negative metastatic breast cancer: the MERIBEL study. Clin Breast Cancer 19:105-112. https://doi.org/10.1016/j.clbc.2018.12.012

[25] Wolff AC, Hammond ME, Hicks DG, Dowsett M, McShane LM, Allison KH, Allred DC, Bartlett JM, Bilous M, Fitzgibbons P, Hanna W, Jenkins RB, Mangu PB, Paik S, Perez EA, Press MF, Spears PA, Vance GH, Viale G, Hayes DF; American Society of Clinical Oncology; College of American Pathologists (2014) Recommendations for human epidermal growth factor receptor 2 testing in breast cancer: American Society of Clinical Oncology/College of American Pathologists clinical practice guideline update. Arch Pathol Lab Med 138:241-256. https://doi.org/10.5858/arpa.2013-0953-SA

[26] Hammond ME, Hayes DF, Dowsett M, Allred DC, Hagerty KL, Badve S, Fitzgibbons PL, Francis G, Goldstein NS, Hayes M, Hicks DG, Lester S, Love R, Mangu PB, McShane L, Miller K, Osborne CK, Paik S, Perlmutter J, Rhodes A, Sasano H, Schwartz JN, Sweep FC, Taube S, Torlakovic EE, Valenstein P, Viale G, Visscher D, Wheeler T, Williams RB, Wittliff JL, Wolff AC (2010) American Society of Clinical Oncology/College Of American Pathologists guideline recommendations for immunohistochemical testing of estrogen and progesterone receptors in breast cancer. J Clin Oncol 28:2784-2795. https://doi.org/10.1200/JC0.2009.25.6529

[27] Cortes J, Hudgens S, Twelves C, Perez EA, Awada A, Yelle L, McCutcheon S, Kaufman PA, Forsythe A, Velikova G (2015) Health-related quality of life in patients with locally advanced or metastatic breast cancer treated with eribulin mesylate or capecitabine in an open-label randomized phase 3 trial. Breast Cancer Res Treat 154:509-520. https://doi.org/10.1007/s10549-015-3633-7

[28] Petrelli F, Cabiddu M, Coinu A, Borgonovo K, Ghilardi M, Lonati V, Barni S (2015) Prognostic role of lactate dehydrogenase in solid tumors: a systematic review and meta-analysis of 76 studies. Acta Oncol 54:961-970. https://doi.org/10.3109/0284186X.2015.1043026

[29] Ding J, Karp JE, Emadi A (2017) Elevated lactate dehydrogenase (LDH) can be a marker of immune suppression in cancer: interplay between hematologic and solid neoplastic clones and their microenvironments. Cancer Biomark 19:353-363. https://doi.org/10.3233/CBM-160336 
[30] Zhao S, Jiang T, Zhang L, Yang H, Liu X, Jia Y, Zhou C (2016) Clinicopathological and prognostic significance of regulatory $T$ cells in patients with non-small cell lung cancer: a systematic review with meta-analysis. Oncotarget 7:36065-36073. https://doi.org/10.18632/oncotarget.9130

[31] Stämpfli MR, Anderson GP (2009) How cigarette smoke skews immune responses to promote infection, lung disease and cancer. Nat Rev Immunol 9:377-384. https://doi.org/10.1038/nri2530

[32] Miyoshi Y, Yoshimura Y, Saito K, Muramoto K, Sugawara M, Alexis K, Nomoto K, Nakamura S, Saeki T, Watanabe J, Perez-Garcia JM, Cortes J (2020) High absolute lymphocyte counts are associated with longer overall survival in patients with metastatic breast cancer treated with eribulin-but not with treatment of physician's choice-in the EMBRACE study. Breast Cancer 27:706-715. https://doi.org/10.1007/s12282-020-01067-2

\section{Figures}


Patients screened and enrolled $(n=201)$

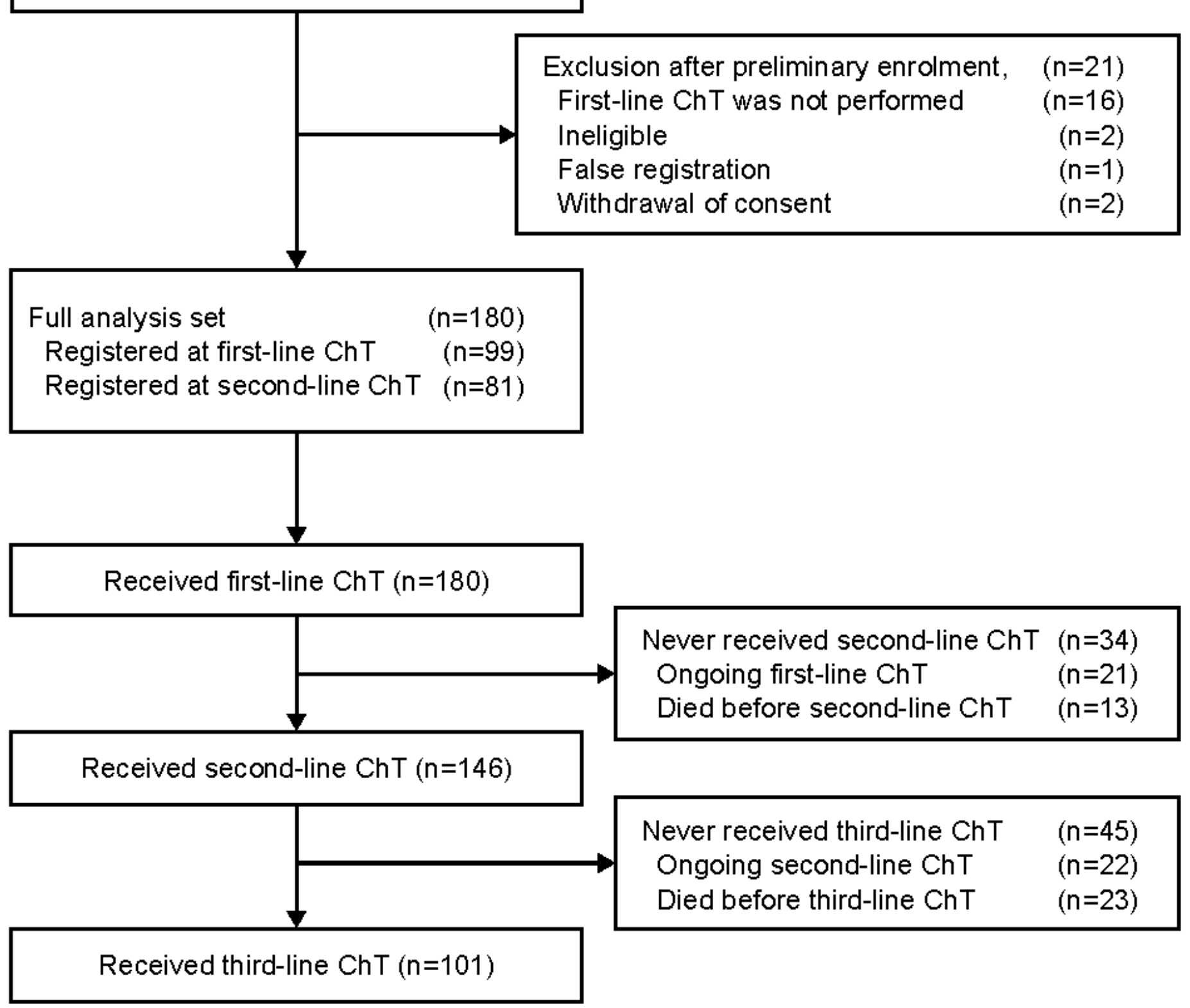

Figure 1

Flow chart of study participant selection. Abbreviation: ChT, chemotherapy 


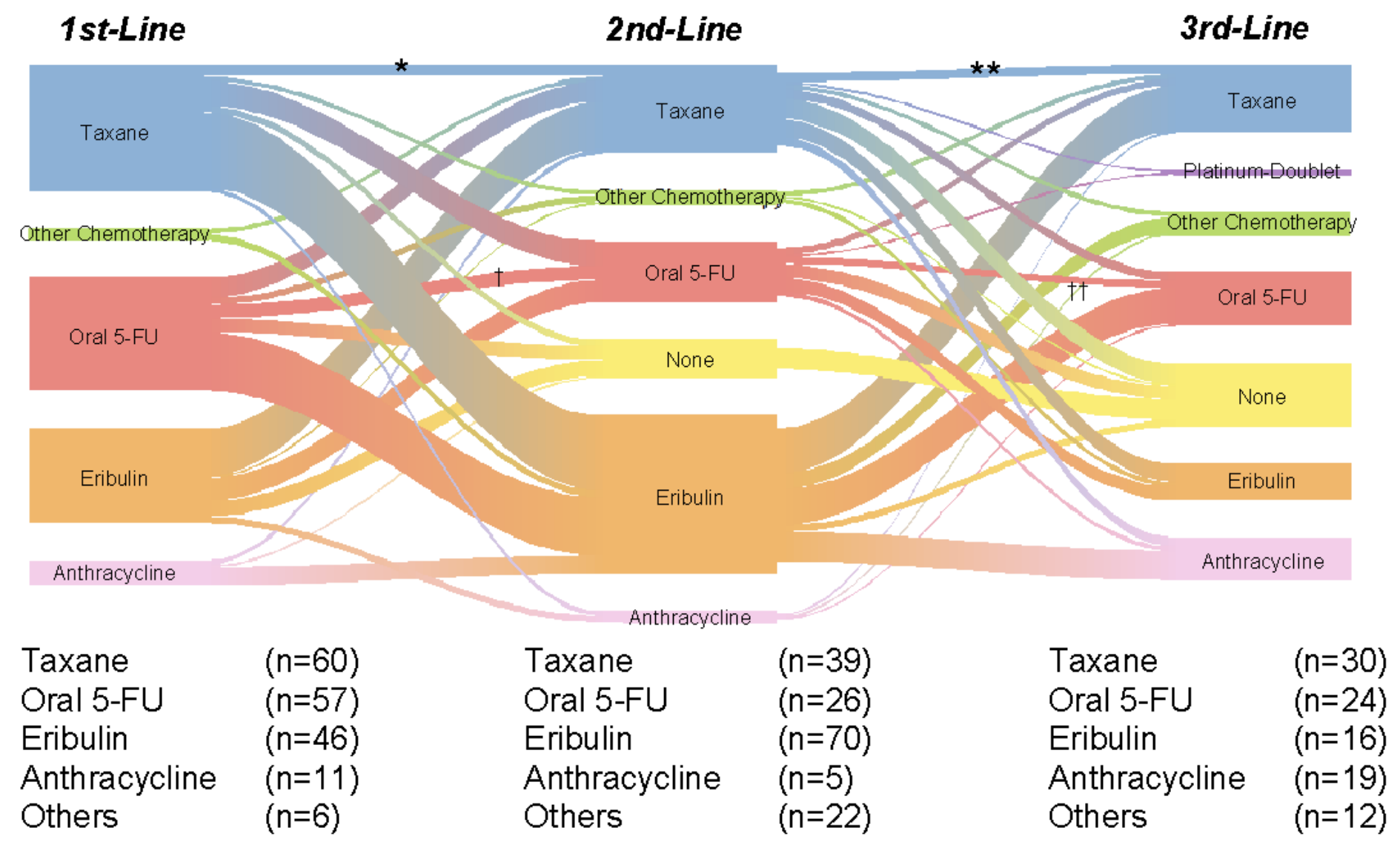

\section{Figure 2}

Trends from first-line to third-line chemotherapy. Taxanes included paclitaxel (PTX) \pm bevacizumab (Bev), nab-paclitaxel (nab-PTX), and docetaxel. Oral 5-fluorouracil (5-FU) included capecitabine (Cape), S-1, and tegafur/uracil (UFT). *PTX was administered in first-line chemotherapy followed by PTX+Bev in secondline chemotherapy in four patients, whereas PTX+Bev was administered in first-line chemotherapy followed by nab-PTX in second-line chemotherapy in one patient. **Nab-PTX second-line chemotherapy followed by PTX+Bev in third-line chemotherapy in two patients, whereas PTX+Bev in second-line chemotherapy was followed by nab-PTX as third-line chemotherapy in two patients. †S- 1 in first-line chemotherapy followed by Cape and UFT in second-line chemotherapy in four and one patients, respectively, whereas Cape in first-line chemotherapy was followed by S-1 in second-line chemotherapy in one patient. ††S-1 in second-line chemotherapy was followed by Cape in third-line chemotherapy in two patients, whereas Cape in second-line chemotherapy was followed by S-1 in third-line chemotherapy in one patient. 
(a)

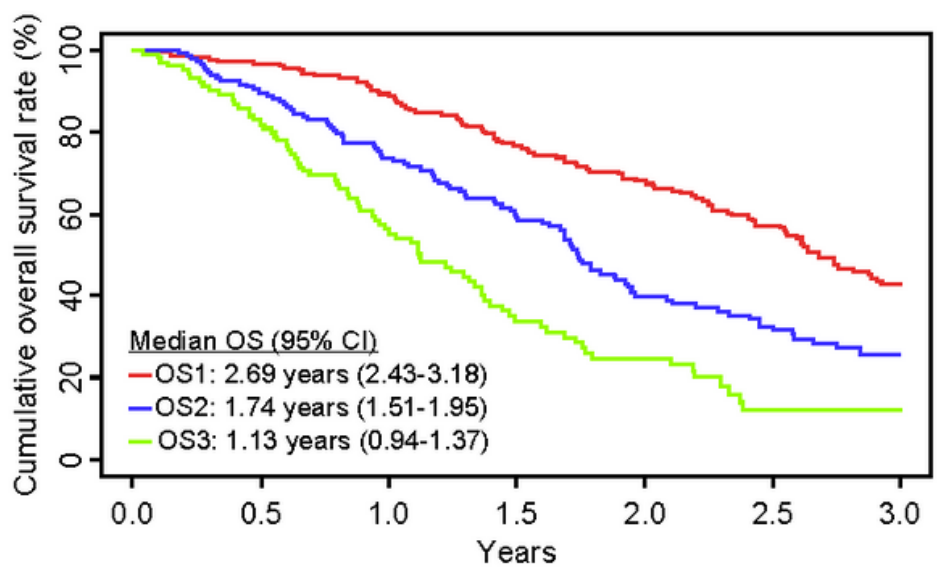

(b)

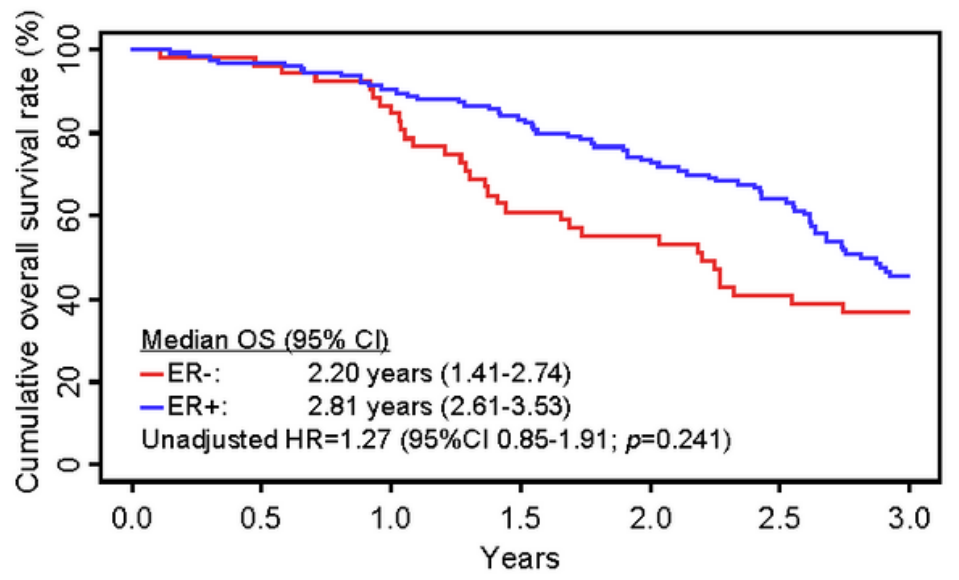

\section{Figure 3}

Kaplan-Meier estimates for overall survival (OS). (a) Analysis stratified by treatment line of chemotherapy in all cohorts. (b) Analysis stratified by the estrogen receptor (ER) status. OS1, overall survival from the initiation of first-line chemotherapy; OS2, overall survival from the initiation of secondline chemotherapy; OS3, overall survival from the initiation of third-line chemotherapy.

(a)

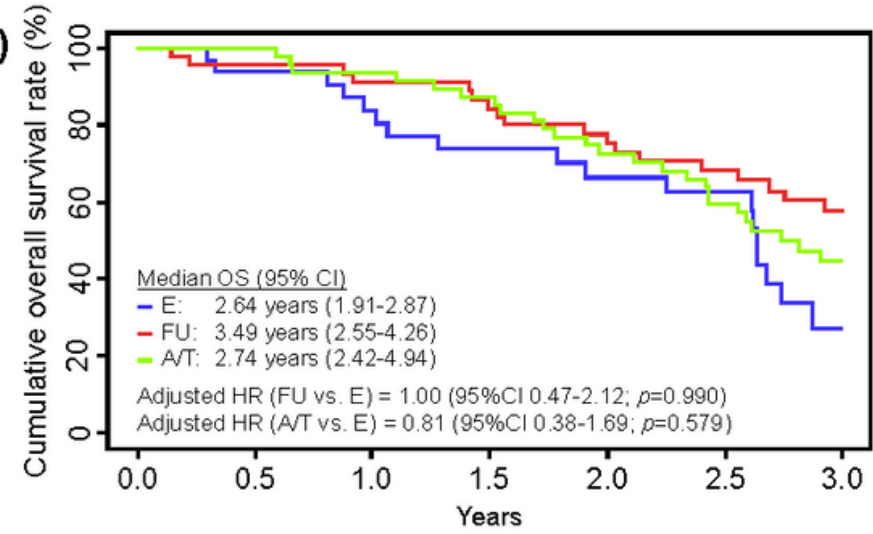

(c)

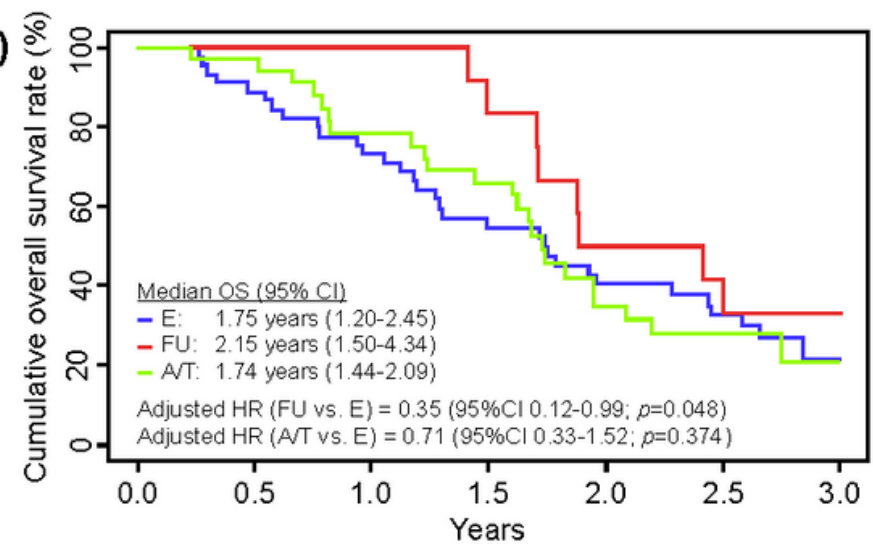

(b)

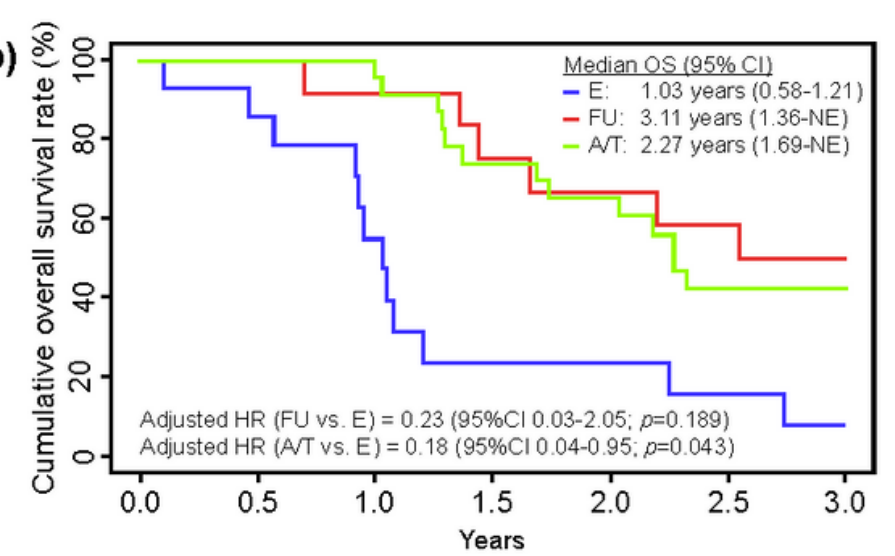

(d)

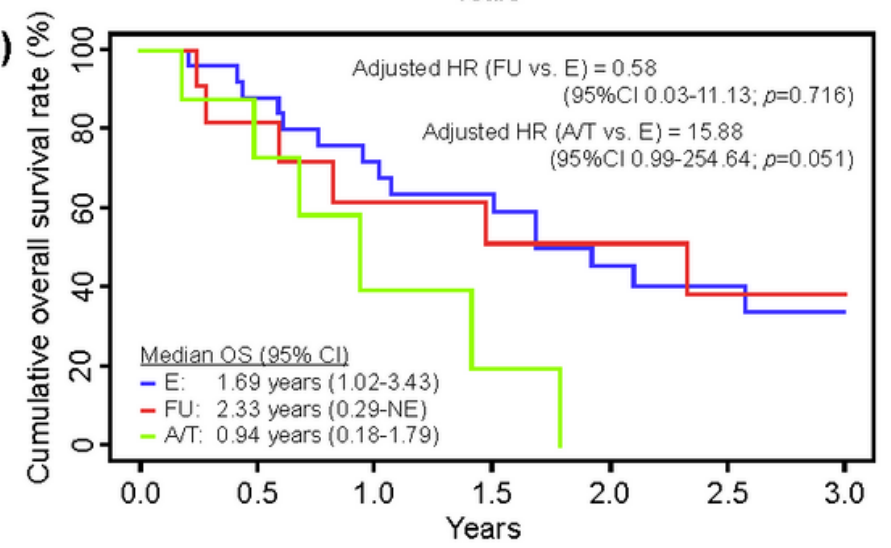

\section{Figure 4}


Kaplan-Meier estimates for overall survival (OS) by estrogen receptor (ER) status and line of chemotherapy. (a) Analysis of the first-line chemotherapy in the ER-positive cohort. (b) Analysis of the first-line chemotherapy in the ER-negative cohort. (c) Analysis of the second-line chemotherapy in the ERpositive cohort. (d) Analysis of the second-line chemotherapy in the ER-negative cohort.

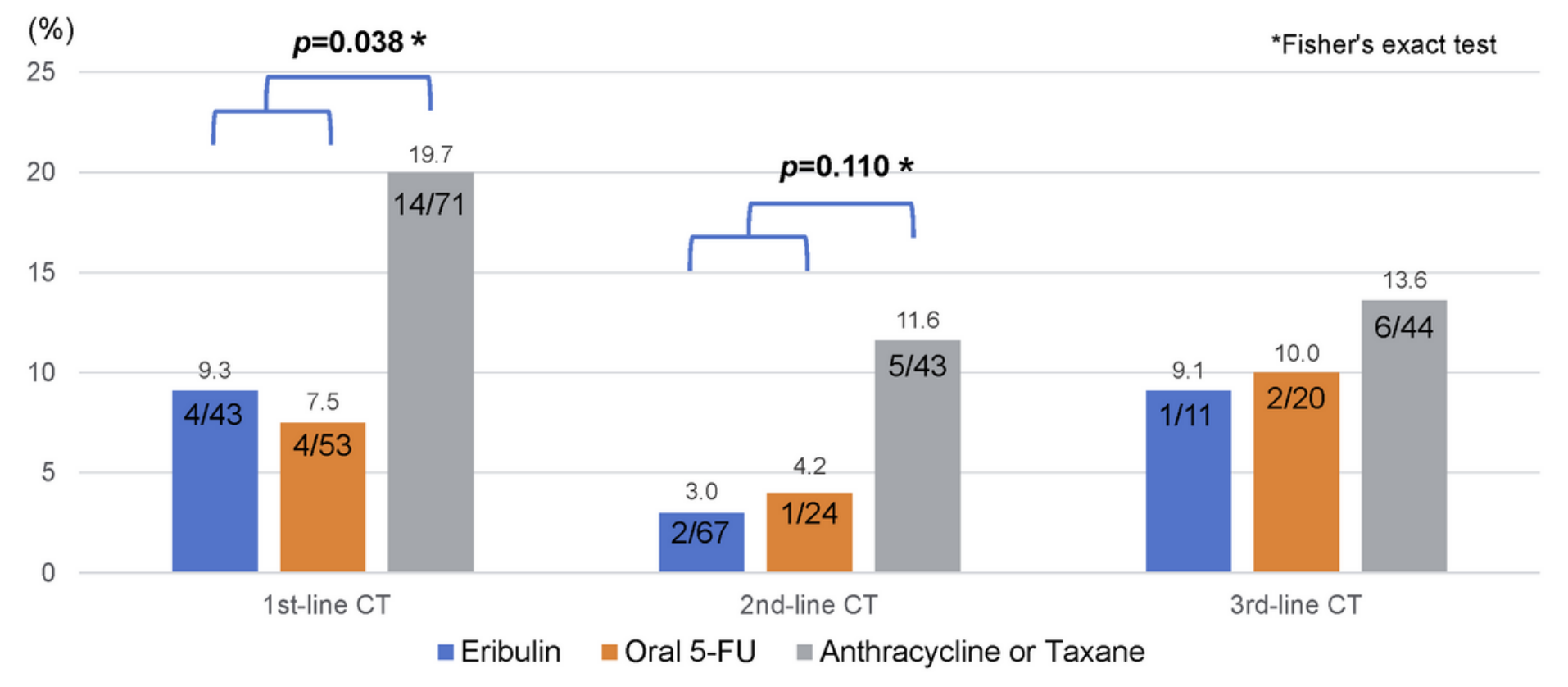

\section{Figure 5}

Proportion of adverse event-related discontinuation for each drug.

\section{Supplementary Files}

This is a list of supplementary files associated with this preprint. Click to download.

- SupplementaryFigS1.pdf

- SupplementaryFigS2.pdf

- SupplementaryTableS1.doc 